\title{
Morphological characteristics, nutritive quality, and methane production of tropical grasses in Brazil
}

\author{
Danilo Montalvão Lima(1), Adibe Luiz Abdalla Filho(2), Paulo de Mello Tavares Lima(2), Gabriel Zanuto Sakita(2), \\ Tairon Pannunzio Dias e Silva( ${ }^{(2)}$, Concepta McManus ${ }^{(1)}$, Adibe Luiz Abdalla(2) and Helder Louvandini( ${ }^{(2)}$
}

(1)Universidade de Brasília, Faculdade de Agricultura e Medicina Veterinária, Brasília, DF, Brazil. E-mail: daniloagro@gmail.com, concepta@unb.br (2)Universidade de São Paulo, Centro de Energia Nuclear na Agricultura, Piracicaba, SP, Brazil. E-mail: adibefilho@cena.usp.br, pmtlima@cena.usp.br, gabrielsakita@usp.br, taironpannunzio@usp.br, abdalla@cena.usp.br, louvandini@cena.usp.br

\begin{abstract}
The objective of this work was to evaluate three tropical forage species for their in vitro methane $\left(\mathrm{CH}_{4}\right)$ production and organic matter degradability, in order to determine the relationships between forage grass nutritive quality and $\mathrm{CH}_{4}$ production. Guinea grass (Megathyrsus maximus), palisade grass (Urochloa brizantha), and signal grass (Urochloa decumbens) were evaluated. Palisade grass showed the highest organic matter, neutral detergent fiber, acid detergent fiber, lignin, and lower-crude protein content. Signal grass had the highest values for hemicellulose and neutral detergent fiber-nitrogen, and the lowest-cellulose content. Guinea grass and signal grass showed a higher-total gas production than palisade grass. Besides, Guinea grass showed an increased $\mathrm{CH}_{4}$ production, and palisade grass showed lower value for truly degraded organic matter, and reduced partitioning factor, in comparison to signal grass. An increased $\mathrm{CH}_{4}$ production was observed in cases of lower hemicellulose and paratitioning factor. The nutritive value and $\mathrm{CH}_{4}$ production of forages may be employed as parameters, aiming at the sustainability of ruminant production.
\end{abstract}

Index terms: Brachiaria, Megathyrsus maximus, Urochloa, livestock, methane production.

\section{Características morfológicas, qualidade nutritiva e produção de metano de gramíneas tropicais no Brasil}

Resumo - O objetivo deste trabalho foi avaliar três espécies de gramíneas tropicais quanto à produção de metano $\left(\mathrm{CH}_{4}\right)$ in vitro e à degradabilidade da matéria orgânica, para determinar as relações entre a qualidade nutritiva das gramíneas e a produção de $\mathrm{CH}_{4}$. $\mathrm{O}$ capim-colonião (Megathyrsus maximus), o capim-braquiarão (Urochloa brizantha) e o capim-decumbens (Urochloa decumbens) foram avaliados. O capim-braquiarão apresentou os maiores teores de matéria orgânica, fibra em detergente neutro, fibra em detergente ácido e lignina, e o menor teor de proteína bruta. O capim-decumbens apresentou os maiores teores de hemicelulose e de nitrogênio em fibra de detergente neutro, além do menor teor de celulose. O capim-colonião e o capimdecumbens apresentaram maior produção total de gases do que o braquiarão. Além disso, o capim-colonião apresentou maior produção de $\mathrm{CH}_{4}$, e o capim-braquiarão, menor degradabilidade verdadeira da matéria orgânica e reduzido fator de partição, em comparação ao capim-decumbens. Maior produção de $\mathrm{CH}_{4}$ foi verificada em casos em que os valores de hemicelulose e fator de partição foram menores. A qualidade nutricional e a produção de $\mathrm{CH}_{4}$ das forragens avaliadas podem ser utilizadas como parâmetros a serem empregados, que visem a sustentabilidade da produção de ruminantes.

Termos para indexação: Brachiaria, Megathyrsus maximus, Urochloa, pecuária, produção de metano.

\section{Introduction}

One of the advantages of grassland-based livestock production is the ruminant ability to transform fibrous feed of relatively low-nutritional value into products for human consumption. Meanwhile, in this process, enteric methane $\left(\mathrm{CH}_{4}\right)$ is produced under anaerobic conditions in the gastrointestinal tract of these animals, via methanogenic Archaea which use carbon-dioxide $\left(\mathrm{CO}_{2}\right)$ and hydrogen $\left(\mathrm{H}_{2}\right)$ to produce $\mathrm{CH}_{4}$ during the microbial degradation of feed (McAllister \& Newbold, 2008). This process is responsible for a significant loss of dietary energy $(5-10 \%)$ that could be redirected potentially towards the production of milk and meat (Eckard et al., 2010; Madsen et al., 2010). 
Brazil has the largest commercial herd of ruminants in the world, and a great part of these animals is kept on tropical pastures (Bueno et al., 2015) which comprises approximately 170 million hectares of grasslands (Bustamante et al., 2012). The genus Urochloa (Syn. Brachiaria) is the most dominant, representing $50 \%$ of pastures of the country because of its remarkable adaptability and productivity in tropical climate conditions (Cabral et al., 2014; Demarchi et al., 2016). However, despite being more challenging and demanding for soil fertility, the use of Megathyrsus maximus is increasing as an option to forage grass due to its high-leaf production and nutritional value, factors that may allow the achievement of a superior animal performance (Fernandes et al., 2014).

However, around $70 \%$ of the Brazilian pasture areas show some degree of degradation (Dias-Filho, 2014; Cherubin et al., 2016), which affects their nutritive value and contributes negatively to the efficiency of the system, impairing animal performance, and increasing the $\mathrm{CH}_{4}$ emission per unit of generated products. In addition to its impacts on the system productivity, $\mathrm{CH}_{4}$ emission by ruminants is also important for the environmental impact of livestock production, since this activity contributes $33 \%$ of the anthropogenic emissions of this greenhouse gas, which has a global warming potential 28 times as higher as that of $\mathrm{CO}_{2}$ (Eckard et al., 2010; Hünerberg et al., 2015).

Sustainable pasture-based ruminant production may be defined as a system that ensures the adequate generation of animal products and profitability of farming with minimal impact on the environment, making it possible to future generations the use of the land, besides counting with the best use of locally available resources and animal welfare as important aspects of the system (Wathes et al., 2013). By this definition, the amount and quality of forage fed to animals are considered crucial factors, especially regarding the mitigation of enteric $\mathrm{CH}_{4}$ emissions. Since the ruminant livestock sector is a major contributor to climate change (O'Mara, 2011), it is essential to investigate and determine the most important factors which affect both directly and indirectly the greenhouse gas emissions in animal production.

The objective of this work was to evaluate three tropical forage for in vitro $\mathrm{CH}_{4}$ production and the organic matter degradability, in order to determine the relationships between forage grass nutritive quality and $\mathrm{CH}_{4}$ production.

\section{Materials and Methods}

The experiment was carried out in accordance with the Brazilian laws of ethics in animal experimentation, and it was approved by the Ethics Committee on Use of Animals of the Escola Superior de Agricultura Luiz de Queiroz (CEUA-Esalq/USP).

Samples of three forage species: the cultivar Áries of Guinea grass (Megathyrsus maximus (Jacq.) B.K.Simon \& Jacobs), palisade grass (Urochloa brizantha, Syn. Brachiaria brizantha), and signal grass (Urochloa decumbens, Syn. Brachiaria decumbens) were collected from plots located at the experimental station Água Limpa, of Universidade de Brasília, Brasília, DF, Brazil, at 1,014 m altitude. According to the Köppen-Geiger's classification, the climate is an Aw type, with hot rainy summers, and cold dry winters (Nimer, 1989). The predominant soil in the area is classified as an Oxisol, which is acidic showing highaluminum and low-calcium and magnesium contents (Libano \& Felfili, 2006).

In December 2007, Guinea grass (15 kg seed ha-1), palisade grass, and signal grass were sown (40 kg seed $\left.h^{-1}\right)$ in three different paddocks ( 0.375 ha each), combined with $\mathrm{P}$ and $\mathrm{K}$ fertilization $\left(20 \mathrm{~kg} \mathrm{ha}^{-1} \mathrm{P}_{2} \mathrm{O}_{5}\right.$, and $\left.60 \mathrm{~kg} \mathrm{ha}^{-1} \mathrm{~K}_{2} \mathrm{O}\right)$, followed by $\mathrm{N}$ fertilization $\left(70 \mathrm{~kg} \mathrm{ha}^{-1}\right.$ $\mathrm{N})$ thirty days later. Each paddock ( $0.375 \mathrm{ha})$ contained only a single grass species, and was divided by electric fences into six parcels of 0.0625 ha. Seventy days after sowing, thirty-six Santa Inês lambs aged four months [21.8 $\pm 4.14 \mathrm{~kg}$ body weight (BW)] were used for grazing in each paddock (12 animals per paddock) for seven days, totaling 35 days of experimental period. From December 2007 to May 2008, the environmental conditions were $21.2^{\circ} \mathrm{C}$ of mean temperature $\left(27.5^{\circ} \mathrm{C}\right.$ maximum, and $14.9^{\circ} \mathrm{C}$ minimum), $83 \%$ mean relative air humidity, $163.9 \mathrm{~W} \mathrm{~m}^{-2}$ mean solar radiation and $1,241.8 \mathrm{~mm}$ of accumulated rainfall. Four samples of $0.25 \mathrm{~m}^{2}$ were collected in random spots in each parcel, leaving plant residues with $20 \mathrm{~cm}$ height (grazing portion of the forage) prior (pre-grazing) to the entrance of animals in each experimental parcels, which was carried out respecting a 7-day interval.

The collected material was weighed and, then, dried at $60^{\circ} \mathrm{C}$, for 72 hours in air-forced oven. After 
that, samples were weighed for determining grass morphological characteristics $\left(\mathrm{kg} \mathrm{ha}^{-1}\right)$ such as available biomass, leaf, stem, and senescent material. Grass nutritive value was assessed by chemical analysis and in vitro gas-production assay, at the laboratory of animal nutrition of the Centro de Energia Nuclear na Agriculture (Lana-Cena/USP).

Dry matter (DM), organic matter $(\mathrm{OM})$, and crude protein $(\mathrm{CP})$ concentrations were determined according to Horwitz et al. (2011). Neutral detergent fiber (NDF) was analyzed according to Mertens (2002), and acid detergent fiber (ADF) and lignin (ADL) were determined sequentially, following the methodology of Van Soest et al. (1991). Hemicellulose (HEMI) and cellulose (CEL) were calculated by the differences between NDF, ADF, and ADL. Also, nitrogen bound to NDF (N-NDF) was determined according to Sniffen et al. (1992).

The $\mathrm{CH}_{4}$ production, the truly degraded organic matter (TDOM), and the in vitro gas production assays were conducted according to the methodology described by Theodorou et al. (1994) and Mauricio et al. (1999), adapted to a semiautomatic system by Bueno et al. (2005).

Eight adults from 6.3 to 1.7-year-old rumencannulated Santa Inês male sheep $(60 \pm 2.5 \mathrm{~kg}$ of BW) were used as inocula donors. The animals fed tropical grass pasture, a concentrate mixture $\left(0.7 \mathrm{~kg} 100 \mathrm{~kg}^{-1}\right.$ BW; $70 \%$ ground corn, and $30 \%$ soybean meal), and had ad libitum access to mineral supplement and water. Before morning feeding, ruminal liquid and solid fractions were collected from each animal, and kept at $39^{\circ} \mathrm{C}$ under anaerobic conditions until inoculation was carried out. Four inocula were prepared (two animals per each inoculum) adopting a 50:50 solid:liquid ratio (on a volume basis) (Bueno et al., 2005).

Half gram of each dried ground grass sample was weighed in filter bags (Ankom F57), and incubated in $160 \mathrm{~mL}$ bottles with $50 \mathrm{~mL}$ of incubation medium (Menke's buffered medium), and $25 \mathrm{~mL}$ of rumen inocula, to complete $75 \mathrm{~mL}$ of final volume and $85 \mathrm{~mL}$ of head space (Longo et al., 2006; Abdalla et al., 2012). The bottles were immediately sealed with $20 \mathrm{~mm}$ butyl septum stoppers (Bellco Glass Inc, Vineland, $\mathrm{NJ}$, USA), then manually mixed and incubated at $39^{\circ} \mathrm{C}$ in a forced-air oven (Marconi MA35, Piracicaba, SP, Brazil) for 24 hours. Two bottles (experimental units) were incubated per grass sample with each one of the four inocula. The same scheme was used for the internal standard samples ['Tifton' hay (Cynodon dactylon)] and blank (bottles without substrate, containing rumen inoculum + medium), to correct the gas production (GP) from the inoculum. Gas pressure was measured using a pressure transducer and data logger (Pressure Press Data 800) at 4:00, 8:00, 12:00 and 24:00 $\mathrm{h}$, in order to determine the GP, using the equation $\mathrm{V}=7.365 \times \mathrm{p}$, in which: $\mathrm{V}$ is the gas volume $(\mathrm{mL})$; and $\mathrm{p}$ is the measured pressure (psi) (Araujo et al., 2011).

For the measurement of $\mathrm{CH}_{4}$ using a gas chromatograph system (Shimadzu GC 2014, Chiyoda$\mathrm{ku}$, Tokyo, Japan), during each one of the pressure measurement events, $2.5 \mathrm{~mL}$ gas samples were collected from the bottles, using $5 \mathrm{~mL}$ syringes, and stored in $10 \mathrm{~mL}$ vacuum tubes, as described by Soltan et al. (2012). Gas production was expressed as $\left(\mathrm{mL} \mathrm{DM}^{-1}\right)$, and $\mathrm{CH}_{4}$ was expressed as a percentage of GP (\%), as well as per unit of truly degraded organic matter ( $\mathrm{mL} \mathrm{g}^{-1}$ TDOM).

The TDOM was determined by neutral detergent solution (NDS) treatment according to Van Soest et al. (1991), but with some modifications. At the end of the 24-hour incubation, all the Ankom F57 (Ankom Technology, Macedon, NY, USA) bags (with the nondegraded samples) were removed from the bottles, and immediately immersed in cold water $\left(-4^{\circ} \mathrm{C}\right)$, so that the microbial fermentation process was interrupted. All the bags were treated with NDS for one hour at $90^{\circ} \mathrm{C}$, washed with hot water and, then, acetone. The $\mathrm{DM}$ and ash of the residual were determined. The difference between the incubated OM sample and the nondegraded residual OM was the TDOM. The partitioning factor (PF) was calculated by the ratio between TDOM (mg) and gas volume $(\mathrm{mL})$ at 24-hour incubation (Blümmel et al., 1997).

The statistical analysis was performed using the software SAS v.9.4 (SAS Institute Inc., Cary NC, USA). The obtained data were subjected to analysis of variance, using the Proc GLM procedure, at 5\% probability. Correlation (Proc Corr) and factor analyses (Proc Factor) were performed to verify the relationships between the plant chemical composition and the in vitro gas production variables. Stepwise (Proc Stepdisc) and canonical (Candisc) discriminant analyses were carried 
out, to verify which characteristics were important in discriminating between the grass species.

\section{Results and Discussion}

In addition to the results of the present study, besides considering grasses grown in the same soil type, temperature, photoperiod, and rainfall conditions, it is important to take into account that using the same grazing management for different grass species may affect their qualitative parameters, such as morphological (Table 1) and chemical characteristics (Table 2). The correlations between grass characteristics and gas production variables are present in Table 3. To minimize possible impairment of these characteristics, it is important to consider the concept of the critical leaf area index (LAI), to determine the moment of grazing or cutting for each grass species, a condition in which the grass canopy intercepts $95 \%$ of the photosynthetically radiation and is near its maximum growth rate, without shading itself (Rhodes, 1971; Parsons et al., 1983). After this moment, the senescence and stem growth rate increase, decreasing the grass nutritive value and leaf production in many grass species (Silva et al., 2015).

Overall, the specific grazing management for each grass can increase the use efficiency of forage by resulting in better canopy structure and nutritive value (Pereira et al., 2015; Anjos et al., 2016), and should be taken into account when discussing the suitability of each of these grass species for the sustainable livestock production in Brazil.

As to the chemical composition, Guinea grass and signal grass showed better nutritive value due to their high-protein and low-fiber contents (Table 2), which leads to improvement of productivity of ruminant livestock in tropical regions. The superior quality characterized by the higher-protein and low-cellulose contents for signal grass was associated with a decrease of their $\mathrm{CH}_{4}$ production (Table 2).

Rumen microbiota requires a minimum crude protein of 70-80 ( $\left.\mathrm{g} \mathrm{kg}^{-1} \mathrm{DM}\right)$ to optimize the breakdown of cell wall components, otherwise, the use of diets with lower-protein levels than these, may result in a reduced feed intake (Van Soest, 1994). Therefore, in a ruminant production system based on grass species, with crude protein content lower than $70 \mathrm{mg} \mathrm{kg}^{-1} \mathrm{DM}$ (as Palisade grass, Table 2), nitrogen supplementation is an alternative that can be used, in order to improve feed intake and digestion by the animals (Sampaio et al., 2010).

The amount of feed intake affects enteric fermentation and $\mathrm{CH}_{4}$ production, even when these are also moderated by feed digestibility and animal characteristics (Hegarty et al., 2007; Liu et al., 2017). In general, increasing feed intake reduces $\mathrm{CH}_{4}$ per unit of consumed feed, which is usually attributed to a shorter time of digesta retention in the rumen, and,

Table 1. Morphological characteristics of the three experimental grass species ${ }^{(1)}$.

\begin{tabular}{|c|c|c|c|c|c|c|c|c|}
\hline \multirow[t]{2}{*}{ Grass species } & \multicolumn{6}{|c|}{ Days } & \multirow[t]{2}{*}{ Mean } & \multirow[t]{2}{*}{ SEM } \\
\hline & 0 & 7 & 14 & 21 & 28 & 35 & & \\
\hline \multicolumn{9}{|c|}{ Available biomass $\left(\mathrm{kg} \mathrm{DM} \mathrm{ha}^{-1}\right)$} \\
\hline Guinea grass & $5,691 \mathrm{~A}$ & $4,200 \mathrm{~A}$ & $3,697 \mathrm{~B}$ & $5,384 \mathrm{~A}$ & $3,212 \mathrm{~B}$ & $4,012 \mathrm{~A}$ & $4,366 \mathrm{~B}$ & 379.16 \\
\hline Palisade grass & $8,511 \mathrm{Aa}$ & $4,606 \mathrm{Ab}$ & 7,732Aab & $8,166 \mathrm{Aab}$ & 7,151Aab & $6,345 \mathrm{Aab}$ & $7,085 \mathrm{~A}$ & 367.12 \\
\hline Signal grass & $6,185 \mathrm{~A}$ & $6,195 \mathrm{~A}$ & $6,438 \mathrm{AB}$ & $6,371 \mathrm{~A}$ & $5,941 \mathrm{AB}$ & $4,724 \mathrm{~A}$ & $5,976 \mathrm{~A}$ & 367.12 \\
\hline \multicolumn{9}{|c|}{ Leaf $\left(\mathrm{kg} \mathrm{ha}^{-1}\right)$} \\
\hline Guinea grass & $361 \mathrm{~A}$ & 787B & 891B & 977B & 482B & 192B & $615 \mathrm{~B}$ & 80.73 \\
\hline Palisade grass & $740 \mathrm{Ab}$ & 1,159Aab & $1,711 \mathrm{Aa}$ & $1,823 \mathrm{Aa}$ & $1,730 \mathrm{Aa}$ & 1,314Aab & $1,413 \mathrm{~A}$ & 78.17 \\
\hline Signal grass & $698 \mathrm{Ab}$ & $1,070 \mathrm{Aab}$ & $1,602 \mathrm{Aa}$ & $1,643 \mathrm{Aa}$ & 1,313Aab & $843 \mathrm{ABab}$ & $1,195 \mathrm{~A}$ & 78.17 \\
\hline \multicolumn{9}{|c|}{ Stem $\left(\mathrm{kg} \mathrm{ha}^{-1}\right)$} \\
\hline Guinea grass & $853 \mathrm{Ab}$ & 3,173Aab & $2,628 \mathrm{Bab}$ & $3,898 \mathrm{Aa}$ & $2,463 \mathrm{Bab}$ & $3,926 \mathrm{Aa}$ & $2,824 \mathrm{~B}$ & 297.34 \\
\hline Palisade grass & $2,530 \mathrm{Ab}$ & 3,377Aab & $5,876 \mathrm{Aa}$ & $6,099 \mathrm{Aa}$ & $5,049 \mathrm{Aab}$ & 4,801ab & $4,622 \mathrm{~A}$ & 287.90 \\
\hline Signal grass & $1,897 \mathrm{~A}$ & $4,729 \mathrm{~A}$ & $4,588 \mathrm{AB}$ & $4,365 \mathrm{AB}$ & $4,285 \mathrm{AB}$ & $3,572 \mathrm{~A}$ & $3,906 \mathrm{AB}$ & 287.90 \\
\hline \multicolumn{9}{|c|}{ Senescence $\left(\mathrm{kg} \mathrm{ha}^{-1}\right)$} \\
\hline Guinea grass & $349 \mathrm{~A}$ & $487 \mathrm{~A}$ & $151 \mathrm{~A}$ & $490 \mathrm{~A}$ & $268 \mathrm{~A}$ & $293 \mathrm{~A}$ & $340 \mathrm{~A}$ & 43.04 \\
\hline Palisade grass & $233 \mathrm{~A}$ & $95 \mathrm{~B}$ & $111 \mathrm{~A}$ & $246 \mathrm{~A}$ & $398 \mathrm{~A}$ & $161 \mathrm{~A}$ & $207 \mathrm{~A}$ & 41.67 \\
\hline Signal grass & $352 \mathrm{~A}$ & $402 \mathrm{AB}$ & $239 \mathrm{~A}$ & $374 \mathrm{~A}$ & $248 \mathrm{~A}$ & $301 \mathrm{~A}$ & $319 \mathrm{~A}$ & 41.67 \\
\hline
\end{tabular}

(1)Means followed by equal letters, uppercase within a column and lowercase within a row, do not differ by Student's test, at 5\% probability. SEM, standard error of the mean. 
consequently, to less extensive fermentation (PinaresPatiño et al., 2003; Yan et al., 2010; Hammond et al., 2013). However, it is important to consider that variations of feed intake not always affect the whole tract digestibility (Molano \& Clark, 2008).

Furthermore, our results showed that grasses with higher biomass amount (Table 1) tend to increase the cell wall fraction, and to decrease the soluble contents of the plants, thus reducing the feed quality (Table 2). Improving forage quality, both through feeding with lower-fiber and higher-soluble carbohydrates can reduce $\mathrm{CH}_{4}$ production (Beauchemin et al., 2008; Hristov et al., 2013). Rodríguez et al. (2007) reported that a proper diet synchronization of available nitrogen and energy for microbial utilization should lead to a decreased $\mathrm{CH}_{4}$ production. Enhancing forage quality (for instance, low-fiber and high-soluble carbohydrates) also tends to increase voluntary intake and to decrease retention time in the rumen, promoting energetically more efficient post-ruminal digestion, and reducing the proportion of dietary energy converted to $\mathrm{CH}_{4}$ (Eckard et al., 2010). Overall, the inverse relation between feed intake level and $\mathrm{CH}_{4}$ yield offers an opportunity to lower emissions while increasing animal productivity (Liu et al., 2017), contributing to the sustainability of livestock production.

Table 2. Chemical composition ( $\mathrm{g} \mathrm{kg}^{-1} \mathrm{DM}$ ), gas production (GP), methane production $\left(\mathrm{CH}_{4}\right)$, truly degraded organic matter (TDOM), and partitioning factor (PF) of the experimental grass species ${ }^{(1)}$.

\begin{tabular}{|c|c|c|c|c|c|}
\hline Parameter $^{(2)}$ & Guinea grass & Palisade grass & Signal grass & $\mathrm{p}$-value & SEM \\
\hline Organic matter $(\mathrm{OM})$ & $941.0 \mathrm{~B}$ & $957.0 \mathrm{~A}$ & $941.0 \mathrm{~B}$ & $<0.0001$ & 1.68 \\
\hline Crude protein $(\mathrm{CP})$ & $102.0 \mathrm{~A}$ & $41.0 \mathrm{~B}$ & $108.0 \mathrm{~A}$ & $<0.0001$ & 54.17 \\
\hline Neutral detergent fiber (NDF) & $708.0 \mathrm{~B}$ & $759.0 \mathrm{~A}$ & $717.0 \mathrm{~B}$ & 0.0110 & 9.75 \\
\hline Acid detergent fiber (ADF) & $466.0 \mathrm{~B}$ & $524.0 \mathrm{~A}$ & $417.0 \mathrm{C}$ & 0.0005 & 11.87 \\
\hline Acid detergent lignin (ADL) & $58.0 \mathrm{~B}$ & $82.0 \mathrm{~A}$ & $52.0 \mathrm{~B}$ & $<0.0001$ & 2.77 \\
\hline Hemicellulose (HEMI) & $242.0 \mathrm{~B}$ & $234.0 \mathrm{~B}$ & $299.0 \mathrm{~A}$ & $<0.0001$ & 4.48 \\
\hline Cellulose (CEL) & $407.0 \mathrm{~A}$ & $442.0 \mathrm{~A}$ & $365.0 \mathrm{~B}$ & 0.0028 & 11.01 \\
\hline N-NDF & $45.0 \mathrm{~B}$ & $33.0 \mathrm{~B}$ & $65.0 \mathrm{~A}$ & 0.0039 & 4.87 \\
\hline TDOM $\left(\mathrm{g} \mathrm{kg}^{-1} \mathrm{OM}\right)$ & $437.2 \mathrm{~A}$ & $378.0 \mathrm{~B}$ & $463.2 \mathrm{~A}$ & 0.0108 & 15.62 \\
\hline Total gas production (GP, $\left.\mathrm{mL} \mathrm{g}^{-1} \mathrm{DM}\right)$ & $116.1 \mathrm{~A}$ & 101.2B & $111.6 \mathrm{~A}$ & 0.0245 & 31.92 \\
\hline $\mathrm{CH}_{4}(\%)$ & $4.8 \mathrm{~A}$ & $3.1 \mathrm{~B}$ & $3.5 \mathrm{~B}$ & 0.0126 & 0.334 \\
\hline $\mathrm{CH}_{4}\left(\mathrm{~mL} \mathrm{~g}^{-1} \mathrm{TDOM}\right)$ & $12.9 \mathrm{~A}$ & $8.3 \mathrm{~B}$ & $8.6 \mathrm{~B}$ & 0.0068 & 0.845 \\
\hline Partitioning factor $(\mathrm{PF})$ & 3.9AB & $3.8 \mathrm{~B}$ & $4.3 \mathrm{~A}$ & 0.0527 & 0.125 \\
\hline
\end{tabular}

(1)Means followed by equal letters within a row, do not differ by Student's test, at $5 \%$ probability. ${ }^{(2)} \mathrm{N}-\mathrm{NDF}$, nitrogen in NDF; values expressed on dry matter basis $\left(\mathrm{g} \mathrm{kg}^{-1} \mathrm{DM}\right) ; \mathrm{CH}_{4}$, methane production as percentage of $\mathrm{GP} ; \mathrm{CH}_{4}\left(\mathrm{~mL} \mathrm{~g}^{-1} \mathrm{TDOM}\right)$, methane production per gram of truly degraded organic matter; TDOM $\left(\mathrm{g} \mathrm{kg}^{-1} \mathrm{OM}\right)$, truly degraded organic matter. SEM, standard error of the means.

Table 3. Pearson correlations coefficients between grass characteristics and gas production.

\begin{tabular}{|c|c|c|c|c|c|c|c|c|c|c|c|c|}
\hline Parameter $^{(1)}$ & $\mathrm{OM}$ & $\mathrm{CP}$ & NDF & $\mathrm{ADF}$ & ADL & HEMI & CEL & N-NDF & GP & $\begin{array}{l}\mathrm{CH}_{4} \\
(\%)\end{array}$ & $\begin{array}{c}\mathrm{CH}_{4} \\
\left(\mathrm{~mL} \mathrm{~g}^{-1}\right. \\
\text { TDOM })\end{array}$ & TDOM \\
\hline Crude protein $(\mathrm{CP})$ & $-0.86^{*}$ & & & & & & & & & & & \\
\hline $\mathrm{NDF}$ & $0.87 *$ & $-0.64 *$ & & & & & & & & & & \\
\hline $\mathrm{ADF}$ & $0.84 *$ & $-0.73^{*}$ & $0.82 *$ & & & & & & & & & \\
\hline $\mathrm{ADL}$ & $0.88^{*}$ & $-0.89 *$ & $0.74 *$ & $0.87 *$ & & & & & & & & \\
\hline Hemicellulose (HEMI) & -0.55 & $0.58 *$ & -0.39 & $-0.85^{*}$ & $-0.71^{*}$ & & & & & & & \\
\hline Cellulose (CEL) & $0.77 *$ & $-0.63^{*}$ & $0.79 *$ & $0.98^{*}$ & $0.77^{*}$ & $-0.85^{*}$ & & & & & & \\
\hline N-NDF & $-0.70^{*}$ & $0.69^{*}$ & $-0.58^{*}$ & $-0.82^{*}$ & $-0.72 *$ & $0.79 *$ & $-0.81^{*}$ & & & & & \\
\hline GP & $-0.81^{*}$ & $0.65^{*}$ & $-0.81^{*}$ & $-0.65^{*}$ & $-0.72 *$ & 0.29 & $-0.58^{*}$ & $0.67 *$ & & & & \\
\hline Methane $\left(\mathrm{CH}_{4}, \%\right)$ & -0.44 & 0.44 & $-0.58 *$ & -0.26 & -0.51 & -0.11 & -0.15 & 0.14 & $0.60^{*}$ & & & \\
\hline $\mathrm{CH}_{4}\left(\mathrm{~mL} \mathrm{~g}^{-1} \mathrm{TDOM}\right)$ & -0.35 & 0.34 & -0.47 & -0.11 & -0.40 & -0.26 & 0.00 & 0.04 & $0.58^{*}$ & $0.97 *$ & & \\
\hline TDOM & $-0.80 *$ & $0.74 *$ & $-0.78^{*}$ & $-0.85^{*}$ & $-0.83 *$ & $0.65^{*}$ & $-0.81^{*}$ & $0.73 *$ & $0.73^{*}$ & 0.40 & 0.22 & \\
\hline Partitioning factor (PF) & -0.40 & 0.47 & -0.34 & $-0.60 *$ & -0.52 & $0.65^{*}$ & $-0.60 *$ & 0.40 & 0.09 & -0.02 & -0.26 & $0.74 *$ \\
\hline
\end{tabular}

${ }^{(1)} \mathrm{NDF}$, neutral detergent fiber; ADF, acid detergent fiber; ADL, acid detergent lignin; N-NDF,- nitrogen in NDF; GP, total gas production; TDOM, truly degraded organic matter. *Significant at $5 \%$ probability. 
Despite the similar gas production showed by Guinea grass and signal grass (Table 2), it is important to consider that $\mathrm{CH}_{4}\left(\mathrm{~mL} \mathrm{~g}^{-1} \mathrm{TDOM}\right)$ is the most adequate parameter to evaluate the $\mathrm{CH}_{4}$ mitigation potential of a given substrate, when performing in vitro assays. In this context, Guinea grass did not show to be the most suitable option due to its increased cell wall content which limits its consumption and nutritional value (Van Soest, 1994) - and $\mathrm{CH}_{4}\left(\mathrm{~mL} \mathrm{~g}^{-1} \mathrm{TDOM}\right)$ production, in comparison with signal grass (Table 2). Furthermore, the increased protein level observed in those grasses contributed to ruminal DM degradability, which consequently led to a higher-gas production (Sallam et al., 2010). In such cases, the increased gas production, as a consequence of the increased degradability, may contribute towards the sustainability of the system as well, since higher-animal production indexes may be observed in those situations, leading to a higher generation of animal products.

The lower-protein content, as well as the highcell wall and lignin found in palisade grass impaired the degradation of its organic matter possibly due to microbial inefficiency (Table 2). This fact led to a lower- gas production and $\mathrm{CH}_{4}\left(\mathrm{~mL} \mathrm{~g} \mathrm{~g}^{-1} \mathrm{TDOM}\right)$ than those of Guinea grass (Table 2). Therefore, it is important to emphasize that the crude protein content of palisade grass was lower than $70 \mathrm{~g} \mathrm{~kg}^{-1} \mathrm{DM}$ (Table 2), which is not enough to sustain an optimal microbial activity to achieve an efficient ruminal fermentation (Van Soest, 1994).

Forages with higher-crude protein and nitrogen content were capable of promoting high-degradation rates by ruminal microbiota for the reason that nitrogen stimulates the microbial growth and ruminal efficiency (Table 2). Methane is a by-product of the breakdown of carbohydrate molecules in the rumen, and characteristics of those (structural or nonstructural ones) are determining factors regarding $\mathrm{CH}_{4}$ production (Hristov et al., 2013). Therefore, despite the similar crude protein levels showed by Guinea grass and signal grass, the increased cellulose content observed for the Megathyrsus species has led to an increased $\mathrm{CH}_{4}$ (Table 2), which explains the positive correlation observed for this plant with both $\mathrm{CH}_{4}$, as a percentage of total gas production, and the degraded organic matter (Figure 1).

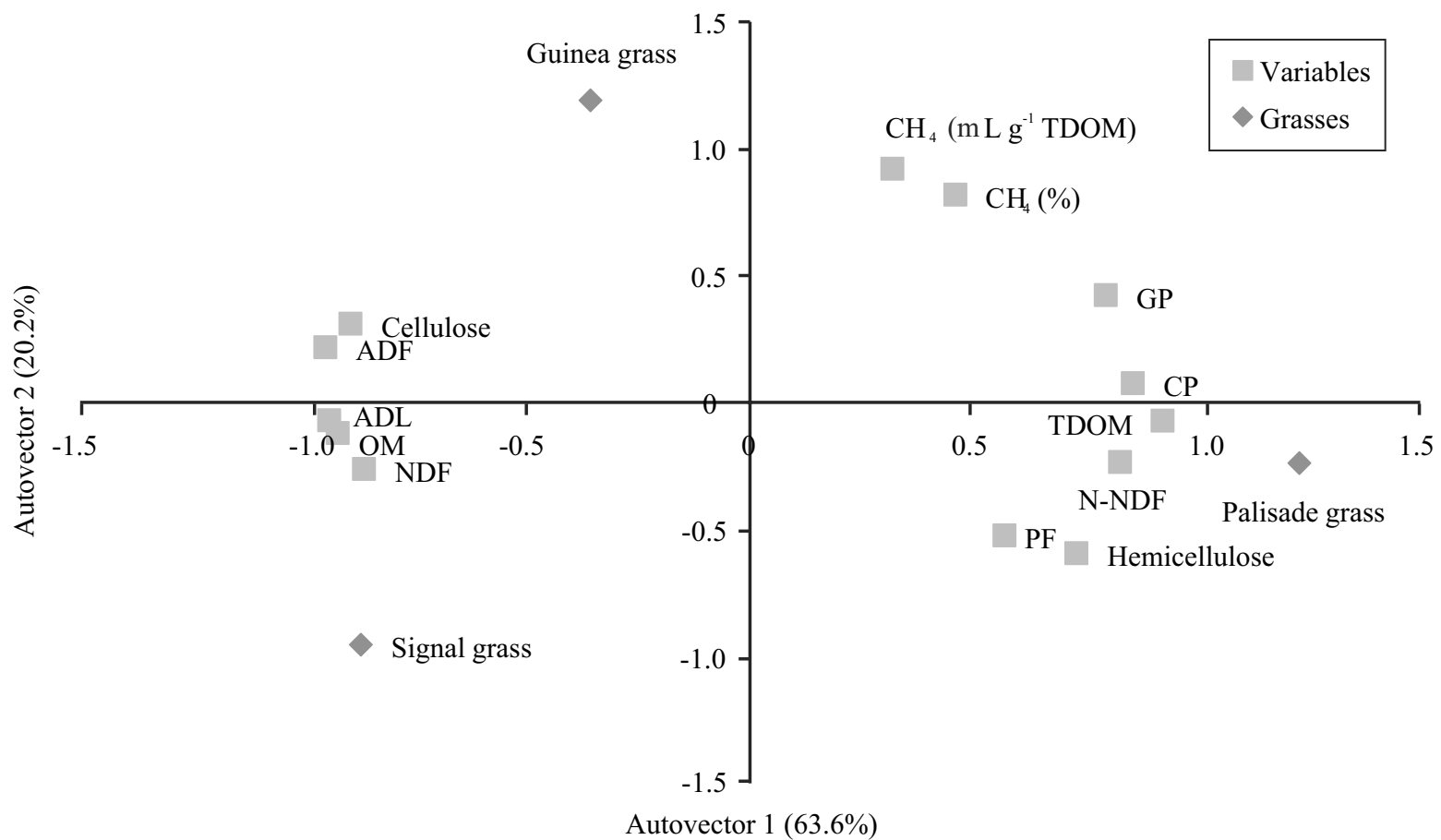

Figure 1. Two main factors analysis showing the relation between plant chemical composition and in vitro gas production variables. OM, organic matter; $\mathrm{CP}$, crude protein; NDF, neutral detergent fiber; ADF, acid detergent fiber; ADL, acid detergent lignin; GP, gas production; N-NDF, nitrogen bound to NDF; TDOM, truly degraded organic matter; and PF, partitioning factor. 


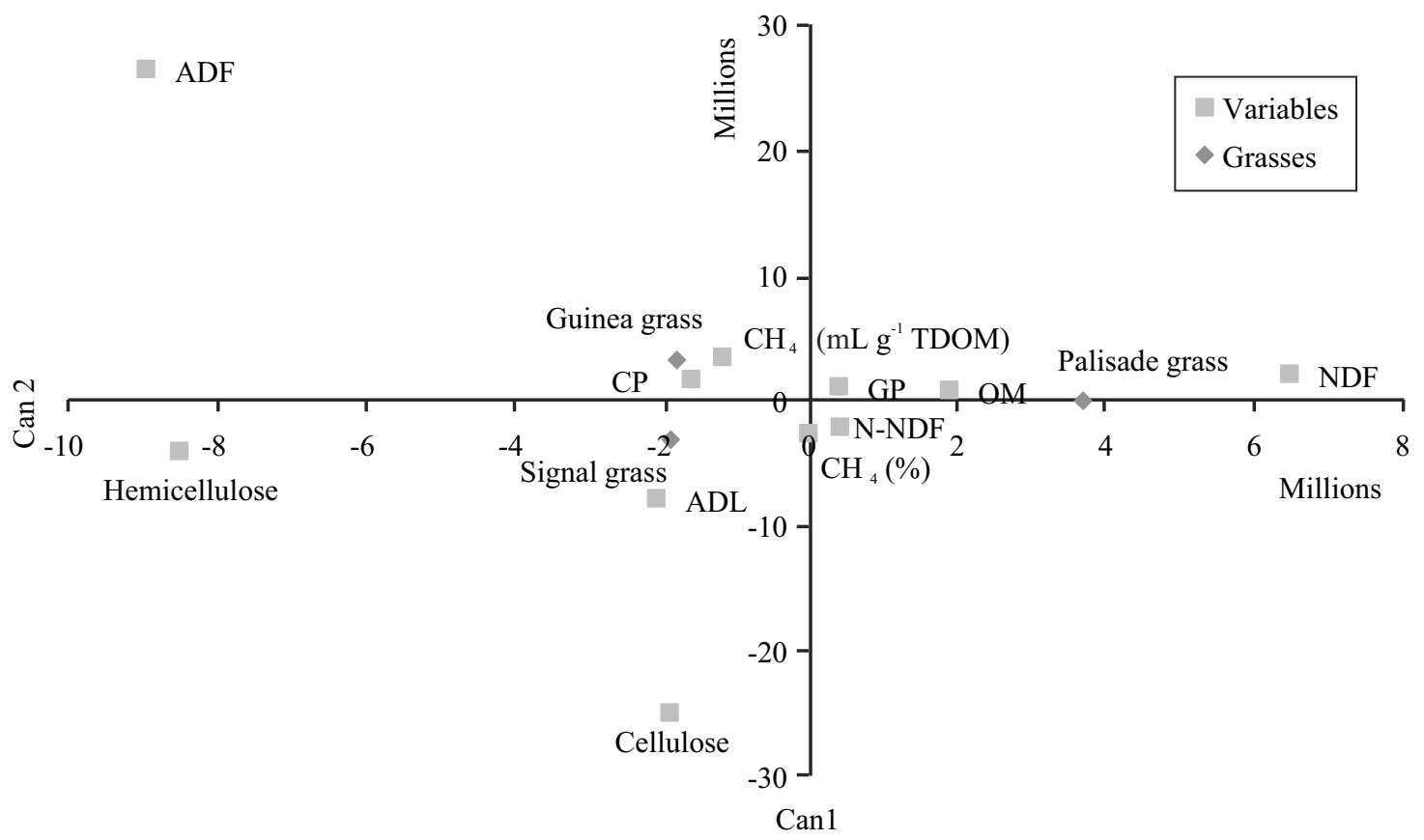

Figure 2. Discriminant canonical (Can) analysis for chemical and gas production variables of in vitro gas production of tropical grasses grazed by sheep. OM, organic matter; $\mathrm{CP}$, crude protein; NDF, neutral detergent fiber; ADF, acid detergent fiber; ADL, acid detergent lignin; GP, gas production; N-NDF, nitrogen bound to NDF; and TDOM, truly degraded organic matter.

The most remarkable discriminatory variable in our study was $\mathrm{CH}_{4}\left(\mathrm{~mL} \mathrm{~g}^{-1} \mathrm{TDOM}\right)$, which was increased in Guinea grass (Figure 2). Generaly, the Megathyrsus grass species shows a better nutritional quality (fiber and protein content) than the Urochloa (Syn. Brachiaria) grasses. Despite that, in the present study, Guinea grass showed a higher-ADF and cellulose content than signal grass (Table 2) which had a higher hemicelulose content (potentially more degradable fiber fraction), possibly due to forage management and soil fertility conditions employed here. However, an in vivo study is necessary to precisely characterize these grass species, considering the animal performance and its methanogenic potential, which are key factors concerning the sustainability of pasture-based ruminant production.

\section{Conclusions}

1. Chemical characteristics and nutritional quality show to be major aspects concerning $\mathrm{CH}_{4}$ production.
2. Despite the similar organic matter degradatibility of Guinea grass with the other grass species, its poorest fiber quality led to an increased $\mathrm{CH}_{4}$ production.

\section{Acknowledgments}

To Conselho Nacional de Desenvolvimento Científico e Tecnológico (CNPq, process No. 303719/2013-3), for financial support; and to the technicians of the Laboratório de Nutrição Animal of the Centro de Energia Nuclear na Agricultura (Cena), for their support.

\section{References}

ABDALLA, A.L.; LOUVANDINI, H.; SALLAM, S.M.A.H.; BUENO, I.C. da S.; TSAI, S.M.; FIGUEIRA, A.V. de O. In vitro evaluation, in vivo quantification, and microbial diversity studies of nutritional strategies for reducing enteric methane production. Tropical Animal Health and Production, v.44, p.953-964, 2012. DOI: 10.1007/s11250-011-9992-0.

ANJOS, A.J. dos; GOMIDE, C.A. de M.; RIBEIRO, K.G.; MADEIRO, A.S.; MORENZ, M.J.F.; PACIULLO, D.S.C. Forage 
mass and morphological composition of Marandu palisade grass pasture under rest periods. Ciência e Agrotecnologia, v.40, p.7986, 2016. DOI: 10.1590/S1413-70542016000100007.

ARAUJO, R.C.; PIRES, A.V.; MOURÃO, G.B.; ABDALLA, A.L.; SALLAM, S.M.A. Use of blanks to determine in vitro net gas and methane production when using rumen fermentation modifiers. Animal Feed Science and Technology, v.166-167, p.155-162, 2011. DOI: 10.1016/j.anifeedsci.2011.04.009.

BEAUCHEMIN, K.A.; KREUZER, M.; O'MARA, F.; MCALLISTER, T.A. Nutritional management for enteric methane abatement: a review. Australian Journal of Experimental Agriculture, v.48, p.21-27, 2008. DOI: 10.1071/EA07199.

BLÜMMEL, M.; MAKKAR, H.P.S.; BECKER, K. In vitro gas production: a technique revisited. Journal of Animal Physiology and Animal Nutrition, v.77, p.24-34, 1997. DOI: 10.1111/j.14390396.1997.tb00734.x.

BUENO, I.C.S.; BRANDI, R.A.; FRANZOLIN, R.; BENETEL, G.; FAGUNDES, G.M.; ABDALLA, A.L.; LOUVANDINI, H.; MUIR, J.P. In vitro methane production and tolerance to condensed tannins in five ruminant species. Animal Feed Science and Technology, v.205, p.1-9, 2015. DOI: 10.1016/j. anifeedsci.2015.03.008.

BUENO, I.C.S.; CABRAL FILHO, S.L.S.; GOBBO, S.P.; LOUVANDINI, H.; VITTI, D.M.S.S.; ABDALLA, A.L. Influence of inoculum source in a gas production method. Animal Feed Science and Technology, v.123-124, p.95-105, 2005. DOI: 10.1016/j.anifeedsci.2005.05.003.

BUSTAMANTE, M.M.C.; NOBRE, C.A.; SMERALDI, R.; AGUIAR, A.P.D.; BARIONI, L.G.; FERREIRA, L.G.; LONGO, K.; MAY, P.; PINTO, A.S.; OMETTO, J.P.H.B. Estimating greenhouse gas emissions from cattle raising in Brazil. Climatic Change, v.115, p.559-577, 2012. DOI: 10.1007/s10584-012-0443-3.

CABRAL, C.H.A.; PAULINO, M.F.; DETMANN, E.; VALADARES FILHO, S. de C.; BARROS, L.V. de; VALENTE, É.E.L.; OLIVEIRA BAUER, M. de; CABRAL, C.E.A. Levels of supplementation for grazing beef heifers. Asian-Australasian Journal of Animal Sciences, v.27, p.806-817, 2014. DOI: 10.5713/ ajas.2013.13542.

CHERUBIN, M.R.; KARLEN, D.L.; FRANCO, A.L.C.; TORMENA, C.A.; CERRI, C.E.P.; DAVIES, C.A.; CERRI, C.C. Soil physical quality response to sugarcane expansion in Brazil. Geoderma, v.267, p.156-168, 2016. DOI: 10.1016/j. geoderma.2016.01.004.

DEMARCHI, J.J.A.A.; MANELLA, M.Q.; PRIMAVESI, O.; FRIGHETTO, R.T.S.; ROMERO, L.A.; BERNDT, A.; LIMA, M.A. Effect of seasons on enteric methane emissions from cattle grazing Urochloa brizantha. Journal of Agricultural Science, v.8, p.106-115, 2016. DOI: 10.5539/jas.v8n4p106.

DIAS-FILHO, M.B. Diagnóstico das pastagens no Brasil. Belém, PA: Embrapa Amazônia Oriental, 2014. 36p. (Embrapa Amazônia Oriental. Documentos, 402).

ECKARD, R.J.; GRAINGER, C.; KLEIN, C.A.M. de. Options for the abatement of methane and nitrous oxide from ruminant production: a review. Livestock Science, v.130, p.47-56, 2010. DOI: 10.1016/j.livsci.2010.02.010.
FERNANDES, F.D.; RAMOS, A.K.B.; JANK, L.; CARVALHO, M.A.; MARTHA JR, G.B.; BRAGA, G.J. Forage yield and nutritive value of Panicum maximum genotypes in the Brazilian savannah. Scientia Agricola, v.71, p.23-29, 2014. DOI: 10.1590/ S0103-90162014000100003.

HAMMOND, K.J.; BURKE, J.L.; KOOLAARD, J.P.; MUETZEL, S.; PINARES-PATIÑO, C.S.; WAGHORN, G.C. Effects of feed intake on enteric methane emissions from sheep fed fresh white clover (Trifolium repens) and perennial ryegrass (Lolium perenne) forages. Animal Feed Science and Technology, v.179, p.121-132, 2013. DOI: 10.1016/j.anifeedsci.2012.11.004.

HEGARTY, R.S.; GOOPY, J.P.; HERD, R.M.; MCCORKELL, B. Cattle selected for lower residual feed intake have reduced daily methane production. Journal of Animal Science, v.85, p.14791486, 2007. DOI: 10.2527/jas.2006-236.

HORWITZ, W.; LATIMER JR., G.W. (Ed.). Official methods of analysis of AOAC International. $18^{\text {th }}$ ed. Gaithersburg: AOAC International, 2011. 2590p.

HRISTOV, A.N.; OH, J.; FIRKINS, J.L.; DIJKSTRA, J.; KEBREAB, E.; WAGHORN, G.; MAKKAR, H.P.; ADESOGAN, A.T.; YANG, W.; LEE, C.; GERBER, P.J.; HENDERSON, B.; TRICARICO, J.M. Mitigation of methane and nitrous oxide emissions from animal operations: I. A review of enteric methane mitigation options. Journal of Animal Science, v.91, p.50455069, 2013. DOI: 10.2527/jas.2013-6583.

HÜNERBERG, M.; MCGINN, S.M.; BEAUCHEMIN, K.A.; ENTZ, T.; OKINE, E.K.; HARSTAD, O.M.; MCALLISTER, T.A. Impact of ruminal $\mathrm{pH}$ on enteric methane emissions. Journal of Animal Science, v.93, p.1760-1766, 2015. DOI: 10.2527/jas.20148469.

LIBANO, A.M.; FELFILI, J.M. Mudanças temporais na composição florística e na diversidade de um cerrado sensu stricto do Brasil Central em um período de 18 anos (1985-2003). Acta Botanica Brasilica, v.20, p.927-936, 2006. DOI: 10.1590/S010233062006000400016.

LIU, Z.; LIU, Y.; SHI, X.; WANG, J.; MURPHY, J.P.; MAGHIRANG, R. Enteric methane conversion factor for dairy and beef cattle: effects of feed digestibility and intake level. Transactions of ASABE, v.60, p.459-464, 2017. DOI: 10.13031/ trans.11744.

LONGO, C.; BUENO, I.C.S.; NOZELLA, E.F.; GODDOY, P.B.; CABRAL FILHO, S.L.S.; ABDALLA, A.L. The influence of head-space and inoculum dilution on in vitro ruminal methane measurements. International Congress Series, v.1293, p.62-65, 2006. DOI: 10.1016/j.ics.2006.03.017.

MADSEN, J.; BJERG, B.S.; HVELPLUND, T.; WEISBJERG, M.R.; LUND, P. Methane and carbon dioxide ratio in excreted air for quantification of the methane production from ruminants. Livestock Science, v.129, p.223-227, 2010. DOI: 10.1016/j. livsci.2010.01.001.

MAURICIO, R.M.; MOULD, F.L.; DHANOA, M.S.; OWEN, E.; CHANNA, K.S.; THEODOROU, M.K. A semi-automated in vitro gas production technique for ruminant feedstuff evaluation. Animal Feed Science and Technology, v.79, p.321-330, 1999. DOI: 10.1016/S0377-8401(99)00033-4. 
MCALLISTER, T.A.; NEWBOLD, C.J. Redirecting rumen fermentation to reduce methanogenesis. Australian Journal of Experimental Agriculture, v.48, p.7-13, 2008. DOI: 10.1071/ EA07218.

MERTENS, D.R. Gravimetric determination of amylase-treated neutral detergent fiber in feeds with refluxing in beakers or crucibles: collaborative study. Journal of AOAC International, v.85, p.1217-1240, 2002.

MOLANO, G.; CLARK, H. The effect of level of intake and forage quality on methane production by sheep. Australian Journal of Experimental Agriculture, v.48, p.219-222, 2008. DOI: 10.1071/ EA07253.

NIMER, E. Climatologia do Brasil. Rio de Janeiro: IBGE, Departamento de Recursos Naturais e Estudos Ambientais, 1989. 422p.

O'MARA, F.P. The significance of livestock as a contributor to global greenhouse gas emissions today and in the near future. Animal Feed Science and Technology, v.166-167, p.7-15, 2011. DOI: 10.1016/j.anifeedsci.2011.04.074.

PARSONS, A.J.; LEAFE, E.L.; COLLET, B.; STILES, W. The physiology of grass production under grazing. 1. Characteristics of leaf and canopy photosynthesis of continuously grazed swards. Journal of Applied Ecology, v.20, p.117-126, 1983. DOI: $10.2307 / 2403380$.

PEREIRA, L.E.T.; PAIVA, A.J.; GEREMIA, E.V.; SILVA, S.C. da. Regrowth patterns of elephant grass (Pennisetum purpureum Schum) subjected to strategies of intermittent stocking management. Grass and Forage Science, v.70, p.195-204, 2015. DOI: $10.1111 /$ gfs.12103.

PINARES-PATIÑO, C.S.; ULYATT, M.J.; LASSEY, K.R.; BARRY, T.N.; HOLMES, C.W. Persistence of differences between sheep in methane emission under generous grazing conditions. The Journal of Agricultural Science, v.140, p.227-233, 2003. DOI: 10.1017/S0021859603003071.

RHODES, I. The relationship between productivity and some components of canopy structure in ryegrass (Lolium spp.): II. Yield, canopy structure and light interception. The Journal of Agriculture Science, v.77, p.283-292, 1971. DOI: 10.1017/ S0021859600024436.

RODRÍGUEZ, R.; SOSA, A.; RODRÍGUEZ, Y. Microbial protein synthesis in rumen and its importance to ruminants. Cuban Journal of Agricultural Science, v.41, p.287-294, 2007.

SALLAM, S.M.A.H.; BUENO, I.C. da S.; GODOY, P.B. de; NOZELLA, E.F.; VITTI, D.M.S.S.; ABDALLA, A.L. Ruminal fermentation and tannins bioactivity of some browses using a semi-automated gas production technique. Tropical and Subtropical Agroecosystems, v.12, p.1-10, 2010.

SAMPAIO, C.B.; DETMANN, E.; PAULINO, M.F.; VALADARES FILHO, S.C.; SOUZA, M.A. de; LAZZARINI, I.; PAULINO, P.V.; QUEIROZ, A.C. de. Intake and digestibility in cattle fed low-quality tropical forage and supplemented with nitrogenous compounds. Tropical Animal Health and Production, v.42, p.1471-1479, 2010. DOI: 10.1007/s11250-0109581-7.

SILVA, S.C. da; SBRISSIA, A.F.; PEREIRA, L.E.T. Ecophysiology of $\mathrm{C}_{4}$ forage grasses - understanding plant growth for optimizing their use and management. Agriculture, v.5, p.598-625, 2015. DOI: 10.3390/agriculture5030598.

SNIFFEN, C.J.; O'CONNOR, J.D.; VAN SOEST, P.J.; FOX, D.G.; RUSSELL, J.B. A net carbohydrate and protein system for evaluating cattle diets: II. Carbohydrate and protein availability. Journal of Animal Science, v.70, p.3562-3577, 1992. DOI: 10.2527/1992.70113562x.

SOLTAN, Y.A.; MORSY, A.S.; SALLAM, S.M.A.; LOUVANDINI, H.; ABDALLA, A.L. Comparative in vitro evaluation of forage legumes (prosopis, acacia, atriplex, and leucaena) on ruminal fermentation and methanogenesis. Journal of Animal and Feed Sciences, v.21, p.759-772, 2012. DOI: $10.22358 / \mathrm{jafs} / 66148 / 2012$.

THEODOROU, M.K.; WILLIAMS, B.A.; DHANOA, M.S.; MCALLAN, A.B.; FRANCE, J. A simple gas production method using a pressure transducer to determine the fermentation kinetics of ruminant feeds. Animal Feed Science and Technology, v.48, p.185-197, 1994. DOI: 10.1016/0377-8401(94)90171-6.

VAN SOEST, P.J. Nutritional ecology of the ruminant. Ithaca: Cornell University Press, 1994. 476p.

VAN SOEST, P.J.; ROBERTSON, J.B.; LEWIS, B.A. Methods for dietary fiber, neutral detergent fiber, and nonstarch polysaccharides in relation to animal nutrition. Journal of Dairy Science, v.74, p.3583-3597, 1991. DOI: 10.3168/jds.S0022-0302(91)78551-2.

WATHES, C.M.; BULLER, H.; MAGGS, H.; CAMPBELL, M.L. Livestock production in the UK in the $21^{\text {st }}$ century: a perfect storm averted? Animals, v.3, p.574-583, 2013. DOI: 10.3390/ani3030574.

YAN, T.; MAYNE, C.S.; GORDON, F.G.; PORTER, M.G.; AGNEW, R.E.; PATTERSON, D.C.; FERRIS, C.P.; KILPATRICK, D.J. Mitigation of enteric methane emissions through improving efficiency of energy utilization and productivity in lactating dairy cows. Journal of Dairy Science, v.93, p.2630-2638, 2010. DOI: 10.3168/jds.2009-2929.

Received on March 17, 2017 and accepted on June 29, 2017 